\title{
Communication
}

[Comunicação]

\section{Brainstem auditory evoked responses in healthy Argentine Mastiff dogs recorded with surface electrodes}

[Evocado auditivo de respostas em cães Mastiff argentino saudáveis rever utilizando eletrodos de superfície]

\author{
M. Armașu, M. Musteață, G.D. Stanciu, D. Mocanu, G. Solcan ${ }^{*}$
}

University of Agricultural Sciences and Veterinary Medicine Ion Ionescu de la Brad Iasi, Romania, 3-8 M. Sadoveanu Alley, 700490

The BAER test has been commonly used in evaluating the auditory function of animals and humans, being the only objective method that can provide the certain diagnosis of deafness (Wilson et al., 2006, Palumbo et al, 2014). Its advantages include being easy to perform, noninvasive, safe and cost-effective, compared with other objective measures of the auditory function. It is not dependent on the level of attention or arousal, having the same values regardless if subjects are sedated or not (Wilson and Mills, 2005). It can evaluate each ear independently, establish a minimal auditory response level, and characterize the type of hearing loss (Wilson and Mills, 2005; Kemper et al., 2013). Representing a valid method to assess the integrity of the auditory pathway in pathological processes of the central nervous system that affect the brainstem region, and it can establish the site of auditory nerve or brainstem injury (Wilson and Mills, 2005).

Adultlike BAER values are obtained by 6 to 8 weeks of age (Wilson and Mills, 2005). Difference occurs when breed and head size is taken into account (Wilson et al., 2006; Kemper et al., 2013; Poma et al., 2008; Munro et al., 1997; Meij et al., 1992; Strain, 2011). However, some authors claimed that the breed might play a more significant role in the obtained BAER measurements than the head size (Poma et al., 2008; Munro et al., 1997), and others state that both characteristics are very important in acquiring BAER values (Meij et al., 1992; Pook and Steiss, 1990). These results indicated that the

Recebido em 19 de abril de 2015

Aceito em 6 de julho de 2015

*Autor para correspondência (corresponding author)

E-mail: gsolcan@uaiasi.ro
BAER test is very important to obtain reference values specific for each breed.

Besides the head size or breed, the examination methodology was also discussed. For performing the BAER test, needle or surface electrodes can be used. The reference ranges of these two types of electrodes are different (Musteata et al., 2013; Cauzinille, 1997) and may have an impact in clinical decisions, suggesting that reference values for each type of electrodes must be obtained.

Argentine Mastiff dogs are included in about 90 breeds genetically predisposed to unilateral or bilateral congenital deafness (Strain, 2011). For this reason, obtaining BAER reference values in this breed is of special importance. In the absence of these normal ranges, all we can do is compare the values obtained at the stimulation of one ear with another. This method is ineffective if the dog has unilateral congenital deafness or hypoacusia.

To the authors' knowledge, until present there are no studies in which BAER waves recorded with surface electrodes in dogs are analysed. The aim of this study is to analyse the BAER waves in Argentine Mastiff dogs by using surface electrodes.

The study was performed on seven Argentine Mastiff healthy dogs, with no hearing or neurological disorders. All dogs were part of the same family. Five of them (two male and three female) were puppies ( 3 dogs were four months 
old, $12-14 \mathrm{~kg}$ weight and 2 dogs were six months old, 26 and $29 \mathrm{~kg}$ ), and 2 dogs were adults (1 male, one year and 5 months old, weighting 38 $\mathrm{kg}$, and 1 female, 2 years of age, weighting $35 \mathrm{~kg}$ ). Before the test, all dogs underwent general anesthesia with medetomidine hydrochloride (Domitor ${ }^{\circledR}$ Phizer-Finland) $30 \mu \mathrm{g} / \mathrm{kg}$ i.m. The use of the animals in this study was approved by the Council of Ethics of the University of Agricultural Sciences and Veterinary Medicine from Iasi (number 438/10.06.2014).

BAER examinations were done with a Neuropack S, MEB 9400K electrodiagnostic system (Nihon Kohden-Japan) in the auditory brainstem response program (ABR). Electrical signals were captured using surface electrodes placed as follows: the active electrode on the vertex, reference electrodes at the base of each ear and the grounding electrode on the median line, retrooccipitally. Attaching the electrodes was done with a special adhesive paste (EEG Paste Elefix ${ }^{\circledR}$ Nihon Kohden - Japan) after the skin was trimmed, degreased with alcohol and dead cells were removed with Pure Skin Nihon Kohden.

Impedance was lower than $5 \Omega$. Alternating click stimuli of $0.1 \mathrm{~ms}$ were applied through earphones inserted into the auditory canal. Stimulus intensities were set at $90 \mathrm{~dB}$ SPL, the non-tested ear being masked with white noise with an intensity $40 \mathrm{~dB}$ lower than that used on the tested ear. Each waveform obtained was the average of 1000 stimulations, using a High-cut filter of 100 $\mathrm{Hz}$ and a Low-cut filter of $3000 \mathrm{~Hz}$ (Arnold, 2007). Artifactual data were automatically rejected; when rejected waveforms represented more than $5 \%$ of the average, the tests were repeated. The waves were manually labeled by the same examiner, each positive peak receiving a roman score from $\mathrm{I}$ through to $\mathrm{V}$, latencies and amplitudes of waves I, III, and V were measured, as well as the intervals I-III, III-V and I-V. The test was repeated after 10 days in order to identify any differences. The final value is considered as a mean of those two examinations.
The results were analysed using the SPSS 20, Wilcoxon Signed Ranks Test for 2 paired samples (to determine the presence/absence of statistical differences between the right and left ear and between an ear (left and right) and binaural stimulation in dogs), and Kruskal Wallis Test for $\mathrm{k}$ independent samples (to determine the presence/absence of statistical differences between dogs BAER values). The significance threshold was $\mathrm{P}<0.05$.

BAER waves recorded with surface electrodes after monoaural (left and right ear) and binaural stimulation with $90 \mathrm{dBSPL}$ intensities are presented in Figure 1.

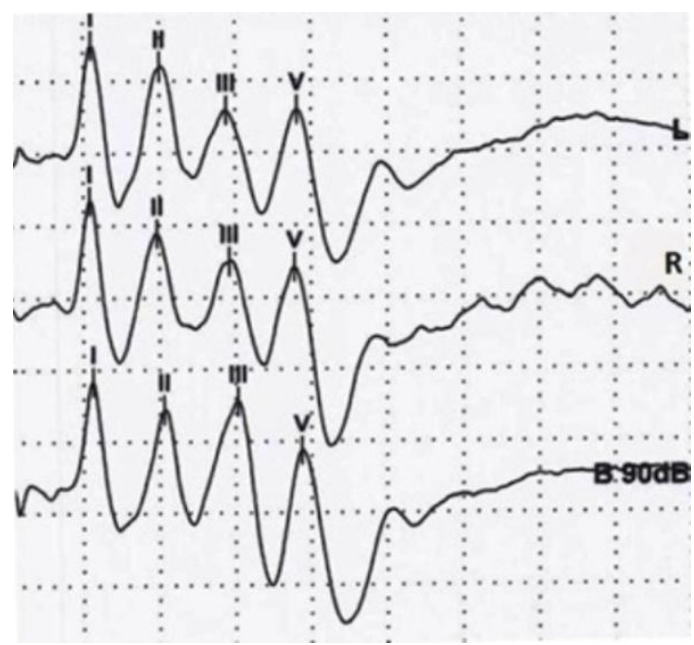

Figure 1. BAER waves recorded with surface electrodes after monoaural (left and right ear) and binaural stimulation with 90 dBSPL intensities.

No significant statistical differences were observed in BAER values between dogs. Even if the current study was conducted on a small number of dogs, our results are similar with Poma (2008) and Munro (1997) and do not support the theory that differences in BAER measurements are due to differences in head size.

The values obtained for latencies and amplitudes of waves I, III and V and interweave latencies IIII, III-V and I-V in monoaural and binaural stimulation are presented in Table 1. 
Table 1. Values of latencies and amplitudes of waves I, III and V and interwave latencies I-III, III-V and $\mathrm{I}-\mathrm{V}$ in monoaural and binaural stimulation obtained for $90 \mathrm{dBSPL}$ sound intensity

\begin{tabular}{lcccc} 
& Left ear & Right ear & Average monoaural & Binaural \\
\hline Latency I & $1.108 \pm 0.027$ & $1.088 \pm 0.021$ & $1.098 \pm 0.025$ & $1.125 \pm 0.068$ \\
Latency III & $2.944 \pm 0.074$ & $2.937 \pm 0.092$ & $2.937 \pm 0.092$ & $3.116 \pm 0.079$ \\
Latency V & $3.925 \pm 0.143$ & $3.73 \pm 0.261$ & $3.827 \pm 0.226$ & $4.009 \pm 0.174$ \\
Amplitude I & $2.33 \pm 0.521$ & $2.382 \pm 0.437$ & $2.356 \pm 0.463$ & $2.146 \pm 0.395$ \\
Amplitude III & $1.202 \pm 0.440$ & $0.955 \pm 0.376$ & $1.079 \pm 0.413$ & $2.448 \pm 0.504$ \\
Amplitude V & $1.855 \pm 0.609$ & $1.808 \pm 0.755$ & $1.832 \pm 0.659$ & $2.452 \pm 1.203$ \\
Interwave latency I-III & $1.835 \pm 0.070$ & $1.841 \pm 0.101$ & $1.838 \pm 0.084$ & $2.010 \pm 0.083$ \\
Interwave latency III-V & $00.981 \pm 0.165$ & $0.8 \pm 0.234$ & $0.890 \pm 0.216$ & $1.806 \pm 0.109$ \\
Interwave latency I-V & $2.817 \pm 0.142$ & $2.641 \pm 0.244$ & $2.729 \pm 0.212$ & $2.924 \pm 0.166$ \\
\hline
\end{tabular}

Comparing the latencies and amplitude values of waves I, III and V and intervawe intervals I-III, III-V and I-V generated by stimulating the left and right ear, no statistically significant differences were observed ( $\mathrm{P}>0.05)$. Conversely, statistically significant changes were obtained for latencies, amplitudes and intervals between mono and binaural stimulation $(\mathrm{P}<0.05)$. Comparing the wave values recorded after binaural and monaural stimulation (left or right), we noticed statistically significant changes for: the latencies of wave III and V for left and right ear, the amplitudes of wave III for left and right ear, the interweave intervals I-III for both left and right ear and interweave intervals $\mathrm{I}-\mathrm{V}$ for right ear. These differences were also observed by other researchers in cats (Musteata et al.,
2013) and humans (Jones and Van der Poel, 1990), being attributed to the delay in the transmission of the impulse on the ascending pathways or to auditory pathway that also included neurons that respond only to binaural stimulation.

Despite the limited number and the genetic relationship between dogs, we consider that the reference ranges obtained in Argentine Mastiff dogs using surface electrodes have an important clinical significance.

Keywords: Brainstem auditory evoked responses, Argentine Mastiff, dog, surface electrodes

\section{RESUMO}

Evocado auditivo de respostas ( BAER ) foi gravado utilizando eletrodos de superfície em sete cães Mastiff argentino saudáveis para estimulações monoaural e binaural em intensidades sonoras de $90 \mathrm{~dB}$ NPS. As latências e amplitudes das ondas I, III e V bem como os intervalos InterWave I- III, III -V e IV foram calculados. As diferenças estatísticas foram obtidas para as ondas III e latências $V$, amplitudes das ondas III e intervalos I- III e I-V entre mono e estimulação binaural. Por serem uma das raças geneticamente predispostas à surdez congênita, obtendo valores de referência BAER, os cães Mastiff argentino têm uma importância clínica especial.

Palavras-chave: evocado auditivo de respostas, Mastiff argentino, cão, eletrodos de superfície

\section{ACKNOWLEDGMENT}

This paper was published under the framework of European Social Fund, Human Resources Development Operational Programme 20072013, project no. POSDRU/159/1.5/S/132765.

\section{REFERENCES}

ARNOLD, S. The auditory brainstem response. In: ROESER, R.; HOSFORD-DUNN, H.; VALENTE'S, M. (Eds.) Auditory: Diagnosis, treatment strategies, and practice management (2nd ed.). NEW YORK: THIEME-MEDICAL PUBLISHERS, p 426-442, 2007 
CAUZINILLE, L. Measure of brainstem auditory evoked response: an objective method to test audition. Point Vet, v.28, p.37-40, 1997.

JONES, S.J.; VAN DER POEL, J.C. Binaural interaction in the brain-stem auditory evoked potential: evidence for a delay line coincidence detection mechanism. Electroencephal. Clin. Neurophysiol., v.77, p.214-224, 1990

KEMPER, D.L.; SCHEIFELE, P.M.; CLARK, J.G. Canine brainstem auditory evoked responses are not clinically impacted by head size or breed. Physiol. Behav., v.110, p.190-197, 2013.

MEIJ, B.P.; VENKER VAN HAAGEN, A.J.; VAN DEN BROM, W.E. Relationship between latency of brain-stem auditory-evoked potentials and head size in dogs. Vet. Quart., v.14, p.121126, 1992.

MUNRO, K.J.; SHIU, J.N.; COX C.L. The effect of head size on the auditory brainstem response for two breeds of dog. Br. J. Audiol., v.31, p.309314, 1997.

MUSTEAȚĂ, M.; NECULAE I.; ARMAȘU, M.; BALAN, C.B. et al. Brainstem auditory evoked potentials in healthy cats recorded with surface electrodes. Acta Vet. Brno., v.82, p.97-101, 2013.
PALUMBO, M.I.P.; RESENDE, L.A.L.; MAYHEW, I.G.J.; BORGES, A.S., Brainstem auditory evoked potential testing in Dalmatian dogs in Brazil. Arq. Bras. Med. Vet. Zootec., v. 66, p.433-438, 2014

POMA, R.; CHAMBERS, H.; COSTA, R.C.; KONYER, N.B. et al. MRI measurement of the canine auditory pathways and relationship with brainstem auditory evoked responses. Vet. Comp. Orthopaed., v.21, p.238-242, 2008.

POOK, H.A.; STEISS, J.E. Correlation of brain stem auditory-evoked responses with cranium size and body weight of dogs. Am. J. Vet. Res., v.51, p.1779-1783, 1990.

STRAIN, G.M. Brainstem auditory evoked response (BAER). In: STRAIN, G.M. (Ed.). Deafness in dogs and cats. Cambridge: CABI, 2011. p.83-85.

WILSON, W.J.; BAILEY, K.L.; BALKE C.L., D'ARBE, C.L. et al. On the dual structure of the auditory brainstem response in dogs. Clin. Neurophysiol., v.117, p.2211-2220, 2006.

WILSON, W.J.; MILLS, P.C. Brainstem auditory-evoked response in dogs. Am. J. Vet. Res., v.66, p.2 177-2187, 2005. 